\title{
MOTYW LIPY CZARNOLESKIEJ W PISMACH CYPRIANA NORWIDA - W KONTEKŚCIE NORWIDOWSKIEGO MYŚLENIA O SZTUCE
}

\section{Uwagi wprowadzające}

Norwidowska refleksja o sztuce (zwłaszcza sztuce narodowej) wiąże się ściśle ze sposobem, w jaki poeta postrzegał twórczość Fryderyka Chopina. Obok utworów, w których Norwid przywołuje postać artysty „naczelnego u nas”, istnieje również utwór poświęcony muzykowi mniej znanemu - młodszemu od autora liryku o cztery lata skrzypkowi. Wiersz Do Nikodema Biernackiego to jedyny stricte literacki utwór Norwida, w którym pojawia się motyw czarnoleskiej lipy. Znajdujemy ów motyw również w jednym z listów - do Józefa Bohdana Wagnera z początku grudnia 1874 roku' Jak wiadomo, urodzony w 1821 roku poeta odwoływał się do tradycji czarnoleskiej także w innych momentach, co dla podjętych tu rozważań ma niemałe znaczenie - motywu symbolicznego drzewa jednak, jak się wydaje, nie nadużył - pozostawiając nam te dwa przywołania.

1 Pomijam zamieszczony w Lekcji VI O Juliuszu Słowackim cytat z pieśni piątej Beniowskiego, zawierający słowa: „I gdyby stary ów Jan Czarnoleski / Z mogiły powstał: to by [ją] zrozumiał, / Myśląc, że jakiś poemat niebieski, / Który mu w grobie nad lipami szumiał / Słyszy, ubrany w dawny rym królewski, / Mową, którą sam przed wiekami umiał" (VI, 461). Wszystkie cytaty z tekstów Norwida wg edycji: Cyprian Norwid, Pisma wszystkie, zebrał, tekst ustalił, wstępem i uwagami krytycznymi opatrzył Juliusz W. Gomulicki, t. I-XI, Warszawa 1971-1976; liczba rzymska oznacza numer tomu, arabska - strony. 
Badając pisma Norwida, warto jednak pamiętać, że nawiązywanie do wątków czy też motywów polskiej tradycji literackiej nie było w jego przypadku czymś rzadkim. O znaczeniu tradycji dla Norwida pisano już wielokrotnie i w różnych kontekstach, i zapewne trudno byłoby wskazać wszelkie prace, które dotykają tego zagadnienia. Początki badań nad tym problemem sięgają czasów II Rzeczypospolitej. Już w 1925 roku Zofia Szmydtowa przedstawiła rozprawę Norwid wobec tradycji literackiej, w której zwróciła uwagę między innymi na znaczenie właśnie poezji Jana Kochanowskiego dla wczesnej twórczości XIX-wiecznego poety; rok później ukazał się krytyczny szkic Tadeusza Makowieckiego poświęcony tej pracy²; a w 1928 roku Makowiecki opublikował artykuł «Promethidion» Norwida a «Dworzanin» Górnickiego ${ }^{3}$, w którym sam podjął zagadnienie zakorzenienia Norwida w tradycji polskiego odrodzenia. Uwagi dotyczące istoty Norwidowskiego pojmowania tradycji jako bliskiej „temu, co zwykliśmy nazywać kulturą w rozumieniu aksjologicznym”, przedstawił wiele lat później w znanej pracy zatytułowanej Norwida wywyższenie tradycji Stefan Sawicki ${ }^{4}$. Problem miejsca tradycji w dziele Norwida został podjęty także w pracach niedawno opublikowanych - Pauliny Abriszewskiej Literacka hermeneutyka Cypriana Norwida (Lublin 2011), Zofii Dambek Cyprian Norwid a tradycje szlacheckie (Poznań 2012), a w ostatnim czasie w książce Agaty Seweryn zatytułowanej Światłocienie i dysonanse. O Norwidzie i tradycji literackiej (Lublin 2013).

Znaczenie tradycji literackiej dla twórczości Norwida wydaje się jednak nadal kwestią niewyczerpaną przez badaczy.

2 Tadeusz Makowiecki, Zofia Szmydtowa, «Norwid wobec tradycji literackiej» (odbitka ze Sprawozd. Gimn. im. Cecylii Plater-Zyberkówny), Warszawa 1925, 8, str. 35, recenzja w: „Ruch Literacki” 1926, R. 1, nr 4, s. 117-118.

3 Tadeusz Makowiecki, «Promethidion» Norwida a «Dworzanin» Górnickiego, „Ruch Literacki” 1928, R. 3, nr 2, s. 40-45.

"Stefan Sawicki, Norwida wywyższenie tradycji, „Studia Norwidiana” 1990, R. 8, s. 3-14. Cyt. za: tegoż, Norwida wywyższenie tradycji, w: tegoż, Wartość - sacrum Norwid. Studia i szkice aksjologicznoliterackie, Lublin 1994, s. 174. 
W Uwagach wprowadzajacych do swoich badań Agata Seweryn słusznie postulowała:

w czasach, gdy uwagę badaczy tak intensywnie zaprzątają kwestie dotyczące postromantyzmu i premodernizmu Norwida, gdy patrzy się na twórczość poety z perspektywy nowoczesności i ponowoczesności, należy tym mocniej upominać się także o docenianie znaczenia dawnej tradycji literackiej w jego dziele ${ }^{5}$.

\section{Norwid a renesans}

Badaczka zwróciła też uwagę na „kluczowe dla tego dzieła” znaczenie między innymi właśnie renesansowej tradycji. Nietrudno - choćby intuicyjnie - stwierdzić, że dla poety, którego nurtowała przecież kwestia tożsamości polskiej narodowej sztuki czy w ogóle polskiej kultury (jak dziś byśmy powiedzieli) spojrzenie na epokę, która w znacznym stopniu określiła kształt literackiej polszczyzny i w której tak bardzo rozkwitła kultura Rzeczypospolitej, musiało być czymś istotnym.

Oczywiście, motywacje tego zainteresowania były również inne. Norwidowi, który nazywał siebie sztukmistrzem, którego upodobania twórcze wiązały się przecież nie tylko z literaturą, ale także ze sztukami plastycznymi, któremu towarzyszyła pasja podróżowania śladami cywilizacji (który Italię traktował w pewnym sensie jako swoją drugą ojczyznę) i który nosił w sobie także pragnienie zdobywania wiedzy na temat historii cywilizacji (dziś powiedzielibyśmy może raczej: historii kultury) - Norwidowi tak usposobionemu kulturowo, poznawczo - niektóre ideały renesansowego humanizmu były szczególnie bliskie ${ }^{6}$.

W liście do Łucji Rautenstrauchowej z lutego 1868 roku poeta pisał: „Prawda, że Rembrandta, da Vinci i Dürera dość studiowałem, i że mam zaszczyt być katolikiem [...]" (IX, 345). Już ten urywek, który znajduje zresztą swoje „dopowiedzenia” w wielu innych tekstach

${ }^{5}$ Agata Seweryn, Światłocienie i dysonanse. O Norwidzie i tradycji literackiej, Lublin 2013, s. 10-11.

6 Wskazywała na to w swojej książce także Agata Seweryn. 
oraz całych dziełach autora, sygnalizuje, że tożsamość Norwida jako artysty i jako człowieka była tożsamością chrześcijańskiego (ściślej: katolickiego) humanisty, w którego rozumieniu pomiędzy światem wielkiej sztuki a wiarą w rzeczywistość duchową wyrażającą się w nauce Kościoła nie musiał zachodzić konflikt, lecz przeciwnie: następować mogło (i powinno) ważkie zbliżenie ${ }^{7}$.

\section{Oryginalność twórcza}

To, na co w skrócie powyżej wskazałem, znajduje swoje potwierdzenie w wypowiedziach Norwida na temat oryginalności twórczej. Poruszenie tego zagadnienia w kontekście rozważań o stosunku poety do tradycji literackiej wydaje się istotne choćby z tego względu, że najbardziej zwięzła, klarowna „definicja” oryginalności, jaką Norwid nam pozostawił, brzmi: „oryginalność jest to s u m i e n n ość w obliczu źródeł"8.

Sformułowanie to - ukute przez poetę-sztukmistrza - może kojarzyć się wprost z odniesieniem do literackiej (czy szerzej: artystycznej) tradycji, tym bardziej, że pojawia się u Norwida nie gdzie indziej, tylko w wykładach O Juliuszu Słowackim. Jednak, jak wskazywał już Tadeusz Makowiecki, a na co niedawno zwrócili uwagę także Kazimierz Świegocki i Marcin Wolniewicz, pojęcie oryginalności posiada w myśli Norwida bardziej złożone znaczenie 9 .

7 Swoje uwagi wiążące się z tym zagadnieniem przedstawiła także Paulina Abriszewska we wspomnianej wcześniej publikacji.

${ }^{8}$ Cyprian Norwid, O Juliuszu Słowackim (VI, 423).

9 Zob. Tadeusz Makowiecki, Norwid myśliciel, w: tegoż, Poeta i myśliciel. Rozprawy i szkice o Norwidzie, zebrali i oprac. Edyta Chlebowska i Włodzimierz Toruń, Lublin 2013, s. 135-145; Kazimierz Świegocki, Cypriana Norwida pojęcie oryginalności, „Zeszyty Naukowe Wyższej Szkoły Rolniczo-Pedagogicznej w Siedlcach”, nr 50, seria: „Nauki Humanistyczne, Filozoficzne i Socjologiczne”, z. 1, Siedlce 1997, s. 109-125; Kazimierz Świegocki, Wizje człowieka w poezji. Analiza antropologiczna twórczości Adama Mickiewicza, Cypriana Norwida i Bolesława Leśmiana, Warszawa 2009, s. 265-290; Marcin Wolniewicz, Historia - polityka - eschatologia. Wizja propagandy powstańczej Cypriana Norwida, „Sensus Historiae” 2012/2, vol. VII, s. 61-76. 
Wydaje się, że poprawne rozumienie Norwidowskiej kategorii oryginalności domaga się odniesienia do dwu „przenikających się" perspektyw, których odpowiednie uwzględnienie stanowić miało warunek zachowania postawy oryginalnej - a zatem twórczej, niebędącej „tępym naśladownictwem”. Z jednej strony myślę tutaj, podobnie jak Świegocki, o perspektywie duchowej, metafizycznej. Wszakże, jak pisał Norwid:

Tylko oryginalność dobrze pojęta, tylko twórczość prawdziwa może utrafić i postawić się czynną w planach Bożych - to jest zwyciężyć bo jedyny Pan, Mistrz nasz i Nauczyciel, jest twórczy wiecznie ${ }^{10}$.

Myślę tu jednak także o perspektywie związków z szeroko pojętą rzeczywistością materialną, której zaniedbanie mogłoby doprowadzić do ukształtowania się naiwnej i fałszywej zarazem postawy duchowej, oderwanej od prawdziwego życia. Norwidowskie pojmowanie oryginalności wiąże się ze swego rodzaju chrześcijańską koncepcją dziejów i odnosi się w myśleniu poety nie tylko - ale także - do świata sztuki. Myśl Norwida o sztuce uwzględnia - co raczej nie zaskakuje - artystyczną tradycję, ale swój szczególny wymiar zyskuje dzięki dostrzeżeniu przez poetę znaczenia rozumianych w świetle chrześcijańskiej wiary „źródeł” duchowych - tworzących jego własną tożsamość, tożsamość religijnego humanisty, ale także tożsamość narodu i całej „Ludzkości”. Jak pisał Sawicki: „Norwid rozumiał dzieje człowieka w perspektywie historii zbawienia"11.

Należy przy tym pamiętać, że według Norwida „korzystanie” z dokonań przeszłości mogło mieć charakter twórczy - bądź zupełnie jałowy. Zwracał na to uwagę Makowiecki:

Norwid był [...] tradycjonalistą w sensie uznawania potrzeby nawiązywań do przeszłości, ale zarazem był wrogiem tradycjonalizmu rozumianego jako powtarzanie czy naśladowanie przeszłości ${ }^{12}$.

10 Cyprian Norwid, O Juliuszu Słowackim (VI, 426).

11 Stefan Sawicki, dz.cyt., s. 169.

12 Tadeusz Makowiecki, Norwid myśliciel, dz.cyt., s. 141. 
Rozumienie Norwidowskiej kategorii oryginalności - o której napisałem tutaj tylko w skrócie - pomaga pełniej zrozumieć obecne w dziełach poety nawiązania literackie (również te zasygnalizowane w tytule mojej pracy), a także lepiej uzmysłowić sobie ich wagę.

Można oczywiście postawić pytanie: dlaczego sięganie do tradycji czarnoleskiej (czy może lepiej: do takich a nie innych elementów tej tradycji) mogło być dla Norwida działaniem pożądanym? Można jednak zapytać także o to, jak nawiązanie do tej tradycji poprzez posłużenie się na przykład motywem czarnoleskiej lipy wybrzmiewa na tle tegoż arcyważnego dla Norwidowskiej filozofii pojęcia - opisanego około 1860 roku, ale pozostającego w zgodzie z wcześniejszą refleksją poety o sztuce przedstawioną choćby w Promethidionie - pojęcia oryginalności. Do odpowiedzi na te pytania postaram się zbliżyć w niniejszej pracy, choć zapewne będzie to zbliżenie tylko częściowe.

\section{Norwid a Kochanowski}

Wypada jeszcze zapytać: kim dla XIX-wiecznego poety był Jan Kochanowski i jak Norwid odnosił się do jego dzieła? Oczywiście jest to odrębne zagadnienie, którego nie omówię tutaj w całości; chciałbym jednak zasygnalizować kilka kwestii.

Nawiązania Norwida do dzieł Kochanowskiego mają różny cel i charakter; pisała o tym w cytowanej przeze mnie pracy Agata Seweryn. Wydaje się sprawą dość oczywistą, że Norwid nie próbował raczej - może poza świadomymi parafrazami - naśladować stylu Jana z Czarnolasu. Poetyckie "pokrewieństwo” nie uwidacznia się też zbytnio na poziomie myśli:

To, co najmocniej zbliża Norwida do Kochanowskiego - pisze Seweryn - to jednak nie, jak chce Szmydtowa, „nawoływania do zachowania równowagi w szczęściu i nieszczęściu, do wypracowania w sobie siły moralnej" $[\ldots]^{13}$.

Chciałbym przypomnieć dobrze znane słowa samego Norwida słowa z nekrologu Fryderyka Chopina. Poeta po śmierci pianisty

13 Agata Seweryn, dz.cyt., s. 42. 
pisał: „Kochanowski w Sobótkach pierwszy ludu poezję uczonemu światu uwidomił - w muzyce Chopin toż uczynił" (VI, 251). Jak wiadomo, Chopin był - wedle Norwida - polskim „artystą naczelnym”, jednak autor Promethidiona pamiętał, że to właśnie Kochanowski był pierwszym, który - poprzez język poezji - „wyraził”, „odkrył dla świata” te pierwiastki twórcze, które tkwiły w kulturze polskiego ludu - jeszcze nie tyle narodu, co ludu. Potrafił podnieść pierwiastki kultury ludowej na wyższy poziom; wyższy - bo przetworzony przez zmysł twórcy wybitnego w swojej epoce, a zarazem rozumiejącego tę kulturę, poniekąd wyrastającego z jej źródeł.

O Norwidowskiej perspektywie „podnoszenia ludowego do Ludzkości” pisano niejednokrotnie; chciałbym jednak zwrócić uwagę na różnicę pomiędzy zawartym w cytowanych powyżej słowach przekonaniem a spojrzeniem Norwida na zwracający się ku twórczości ludowej nurt polskiej XIX-wiecznej poezji, wyrażonym na przykład w liście do Władysława Bentkowskiego z listopada 1867 roku:

Ani Polacy, ani język polski nie mają pojęcia o istnej liryce - to, co Polacy nazywają liryką, jest zawsze mazurkiem i tętnem pańszczyźnianych cepów na klepisku - to zawsze młockarnia i pańszczyzna kroku w niczym nie zrobili naprzód - oni by radzi lirykę Ezechiela na nutę Trzeciego maja mazurkiem podrygać w butach palonych - ram tam tam! ram tam tam! [IX, 331]

W tym zróżnicowaniu odniesień zarysowuje się opozycja, którą autor w swoich wykładach o Słowackim określał, posługując się kategoriami oryginalności i naśladownictwa.

Norwidowskie odwołania do twórczości Kochanowskiego - bez względu na ich konkretny zakres znaczeniowy - są zawsze jakimś wskazaniem na źródła polskiej narodowej literatury, zwłaszcza poezji, a także na źródła „osobistego” poetyckiego świata autora Vade-mecum.

\section{Motyw lipy czarnoleskiej w liście do Józefa Bohdana Wagnera}

List do Józefa Bohdana Wagnera dotyczył w gruncie rzeczy spraw innych niż artystyczne - autor odpowiadał w nim na mandat otrzymany od Komitetu Lwowskiego w sprawie prześladowanych unitów; 
jak podaje Kalendarz życia i twórczości Cypriana Norwida: „List dotyczy uczczenia unitów, którzy zginęli w 1874 r. na Podlasiu i Lubelszczyźnie, broniąc swoich kościołów przed wprowadzanym siłą obrządkiem prawosławnym [...]"14. Norwid przedstawił w tym liście swoją propozycję uczczenia unitów poprzez między innymi umieszczenie marmurowej tablicy na Wawelu oraz uroczyste nabożeństwo żałobne, jako zaś swego rodzaju analogię wobec tej sprawy poruszył zupełnie inną kwestię - przypominając, nie bez ironii, o postawie „obywatelstwa lirycznego" po śmierci Wincentego Pola:

Kiedy zmarł Wincenty Pol, obywatelstwo 1 i r y c z n e pomyślało poetę pogrześć na Wawelu.

Zapłakałem $\mathrm{w}$ duchu, bo to nie dlatego oni pomyślili, iż $\mathrm{Rz}$ [eczpospo]lita zniewieściała już, ale dlatego, iż żadnego poety nigdy za żywota nie u-wdzięczyli, przeto hojnymi muszą być i są po zgonach.

Atoli dla Poety jest pi ó ro podane ręką piękną i zacną, albo odłamek lipy starej z C z a r n ole si a, albo kwiat z mogiły jakiej, albo komitet $\mathrm{z}$ drukarzy i księgarzy ofiarujący się itp. ${ }^{15}$.

Te ironiczne uwagi wiązały się z refleksją poety o braku w narodzie „h i s t orycznej i jaw nej” inteligencji, która „gdybybyła, naród żyłby" - stwierdził autor (X, 33).

Ów „odłamek lipy starej z C z a r n o le s i a” jawi się w wypowiedzi Norwida jako sentymentalna quasi-relikwia - rzecz, od której o wiele bardziej potrzebna jest możliwość tworzenia w społeczeństwie zdolnym do podjęcia trudu myślenia nie „sentymentalnego”, ale twórczego; myślenia, które pozwoliłoby rozpoznawać właściwe miejsce w czasie dla słów i czynów, a poeci mogliby wówczas nawiązać z tym

\footnotetext{
14 Kalendarz życia i twórczości Cypriana Norwida, Poznań 2007,t. II: 1861-1883 (Zofia Trojanowiczowa, Elżbieta Lijewska przy współudziale Małgorzaty Pluty), s. 575. Do wydarzeń z 1874 roku nawiązuje także mniej odległa historia. Wśród unitów, którzy wówczas zginęli, byli męczennicy z Pratulina - beatyfikowani 6 października 1996 roku przez Jana Pawła II. Błogosławionych Wincentego Lewoniuka i Towarzyszy Kościół wspomina w liturgii 23 stycznia.

15 List do Józefa Bohdana Wagnera, [Paryż, początek grudnia 1874] (X, 32-33).
} 
społeczeństwem twórczy dialog. Refleksja ta wpisuje się w obecne u Norwida także dużo wcześniej uwagi o zbyt małym znaczeniu inteligencji w polskim życiu społecznym. Jej nieobecność - wskazywał Norwid - stwarza przestrzeń dla postaw niewczesnych:

Alić żywi tylko i czujni (tj. jedyni dobrzy Obywatele) świadczyć na czas umieją. Umarli, że tu wulgarnie wyrażę się, jedno tylko zawsze na czole noszą - to jest: „Nie poznała babka swojej wnuczki w tańcu".

U ludów gasnących jest tylko inteligencja k on spir a c y j n a albo intrygancka $[\ldots]^{16}$.

Obecność prawdziwej inteligencji była zatem, według Norwida, potrzebna także poezji i poetom - aby ci mogli zostać na czas i właściwie „odczytani”, zrozumiani. Świat sztuki - zdaje się sygnalizować poeta - to także świat myśli, który potrzebuje odpowiednio ukształtowanej publiczności. Nietrudno jednak usłyszeć w słowach Norwida także echa jego osobistych artystycznych niepowodzeń i niezrozumienia ze strony rodaków, którzy przecież i jego nie potrafili właściwie „u-wdzięczyć”.

\section{Motyw lipy czarnoleskiej w wierszu Do Nikodema Biernackiego}

Problematyka zadań artysty i sztuki, sensu, celu twórczości artystycznej wypełnia natomiast treść powstałego w 1857 roku wiersza Do Nikodema Biernackiego (I, 268-269). O utworze tym pisano niejednokrotnie, był on przedmiotem także mojej wcześniejszej pracy ${ }^{17}$. Jak wskazywał Mieczysław Jastrun:

\footnotetext{
16 Tamże (X, 33).

17 Zob. Kazimierz Wyka, Cyprian Norwid. Poeta i sztukmistrz, Kraków 1948, s. 72; Mieczysław Jastrun, Gwiaździsty diament, Warszawa 1971, s. 89-90; Andrzej Gniazdowski, "Pod lauru szerokiego cieniem», „Poezja” 1978, nr 3, s. 26-28; Julian Maliszewski, Cypriana Kamila Norwida słuchanie muzyki, w: C.K. Norwid. W setną rocznicę śmierci poety, pod red. Jerzego Pośpiecha, Opole 1984, s. 101-102; Władysław Stróżewski, Wstęp do: Cyprian Norwid o muzyce, oprac. W. Stróżewski, Kraków 1997, s. 16, 23, 32-34, 46; Zofia Trojanowiczowa, O wierszu «Do Nikodema Biernackiego», w: Rozjaśnianie ciemności. Studia i szkice o Norwidzie, pod red.
} 
W wierszu Do Nikodema Biernackiego, w utworze zadziwiającym przez swoją skomplikowaną, lecz zarazem przezierczą myśl, [Norwid] mówi o życiu sztuki i o losie artysty, w tym wypadku muzyka, w gwałtownych skrótach, które dla nieobeznanego z całością dzieła Norwida mogą wydać się hieroglificzne, lecz które w istocie zawierają cały program Norwida-artysty, program pełen sprzeczności i przezwyciężeń tych właśnie sprzeczności ${ }^{18}$.

Przypomnijmy: we wrześniu 1857 roku Biernacki przybył do Paryża, gdzie miał wystąpić w Sali Pleyela. Zagrał tam w roku 1858, natomiast wcześniej grywał $\mathrm{w}$ polskich salonach ${ }^{19}$. Według Zofii Trojanowiczowej:

Wrażenia i refleksje zawarte w wierszu Norwida musiały być wywołane takim właśnie występem salonowym [...] gromadzącym niewielu słuchaczy, stwarzającym okazję do bezpośredniej wymiany zdań, także z koncertującym artystą ${ }^{20}$.

Utwór ukazał się drukiem w „Dzienniku Literackim” 10 października 1857 roku, co wskazuje na niedługi czas, który dzielił spotkanie artystów i jego powstanie ${ }^{21}$. W pierwszych wersach utworu poeta stawia adresatowi retoryczne pytanie:

...A Ty skąd wziąłeś na te skrzypce deski, Jeśli nie z lipy bogdaj czarnoleskiéj -

„Początek wiersza [...] - pisał Władysław Stróżewski - nabiera, obok sensu metaforycznego, także szczególnego momentu dosłowności, gdy się pamięta, że Biernacki nie tylko był znakomitym wirtuozem,

Jacka Brzozowskiego i Barbary Stelmaszczyk, Kraków 2002, s. 73-81; Bartłomiej Łuczak, O skrzypcach oraz ich muzyce w wierszu do «artysty zapomnianego» - «Do Nikodema Biernackiego», „Studia Norwidiana” 2013, R. 31, s. 91-116.

18 Mieczysław Jastrun, Gwiaździsty diament, dz.cyt., s. 89-9o.

19 Zob. Zofia Trojanowiczowa, O wierszu «Do Nikodema Biernackiego», dz.cyt., s. $74-76$.

20 Tamże, s. 76.

21 Zob. tamże, s. 74, 76-77. 
ale i zajmował się amatorsko lutnictwem"22. Uwaga ta wydaje się nie tylko ciekawa, ale i cenna - i nie od rzeczy będzie stwierdzenie, że przywołany fakt mógł zainspirować poetę tworzącego znamienną metaforę. Kto wie - może w trakcie swobodnej rozmowy obu artystów padło, zadane przez Norwida, pytanie o pochodzenie instrumentu, może panowie rozmawiali o jakichś szczegółach związanych z jego budową, a to sprowokowało skrzypka także do podzielenia się z rozmówcą-sztukmistrzem prawdą o swoim własnym lutniczym doświadczeniu...? Oczywiście, są to tylko domniemania. $Z$ pełnym przekonaniem można natomiast stwierdzić, że w pierwszych wersach utworu pojawia się bardzo ważna metafora. Pisałem o tym we wcześniejszym artykule:

Obraz poetycki, wskazujący poniekąd na budulec instrumentu, zawiera jednak w sobie bardzo konkretne i „silne” odwołanie. Słynna lipa z Czarnolasu to przecież znak tożsamości polskiej poezji ${ }^{23}$.

Odwołanie to posiada tutaj oczywiście kluczowe znaczenie. „Kochanowski w Sobótkach pierwszy ludu poezję uczonemu światu uwidomił - w muzyce Chopin toż uczynił" - pisał Norwid. Pytanie skierowane do skrzypka w poświęconym mu wierszu jest zwróceniem uwagi na istotne dla artysty źródła. Zadanie Biernackiego jest podobne do tego, które wcześniej wypełnili Kochanowski oraz Chopin.

Tożsamość artysty nie może być oderwana od tożsamości narodu, z którego on sam wyrasta - a tożsamość narodu jest zakorzeniona w tradycji ludu. Działalność artystyczna Biernackiego jest kolejnym ogniwem, kontynuacją procesu rozwoju polskiej kultury - która bierze początek z „poezji ludu”. Muzyka grana przez skrzypka - sygnalizuje Norwid - to owoc polskiej tradycji. Słowa Norwidowego liryku dają się odczytywać jako swego rodzaju przypomnienie o tej prawdzie, ale także jako wyraz dostrzeżenia przez poetę postawy wcielanej w życie przez artystę-skrzypka. Jak wskazałem w cytowanej pracy: „Nie bez znaczenia dla poety mógł być repertuar koncertowy młodszego od niego o kilka lat muzyka"24, o którym Józef Reiss pisał:

22 Władysław Stróżewski, Wstęp do: Cyprian Norwid o muzyce, dz.cyt., s. 16.

23 Bartłomiej Łuczak, O skrzypcach oraz ich muzyce..., dz.cyt., s. 93.

24 Tamże. 
„Również sławny był w Polsce i zagranicą Nikodem Biernacki [...] gdy jako wykonawca fantazji na tematy polskie krzepił grą swoją serca rodaków"25.

Metafory zawarte w kolejnych wersach liryku:

I smyk Twój jestże czarodziejstwem żywy

$\mathrm{Z}$ białego konia arabskiego grzywy?...

I struny Twoje - czy Ty ręką lewą

Spod serca wsnułeś na skrzypców Twych drzewo?

$[\mathrm{I}, 268]$

wskazują na kunszt instrumentalny skrzypka oraz na potrzebę złączenia tego kunsztu z głębią osobowości artysty ${ }^{26}$. Sztuka zatem zdaje się wskazywać Norwid - czerpie z głębi ducha konkretnego twórcy, a także z głębi tradycji jego narodu, swój ostateczny kształt zaś, formę, zawdzięcza pracy artysty nad doskonaleniem umiejętności, które - w przypadku muzyka-instrumentalisty - wiążą się $\mathrm{z}$ wybitnym opanowaniem gry na danym instrumencie. Bliski jest tutaj autor wiersza przekonaniom wyrażonym niedługo potem w Lekcji III O Juliuszu Słowackim, w której podjął próbę nakreślenia istoty „twórczości prawdziwej”27.

Skojarzenie skrzypiec z czarnoleską lipą zostaje w poetyckiej wizji Norwida w ciekawy sposób „uzupełnione” o określenie „złamek drewna”:

Powiem - iż wieszczów rzecz jest poznać wieszcze:

Oto - zaklęta dała Ci królewna

Klucze od Echa i ten złamek drewna,

I łzę, i poszept w ucho - i grom jeszcze!...

$[\mathrm{I}, 268]$

Ponownie posłużę się urywkiem mojej interpretacji liryku:

Bez względu na to, czy intencją poety było nazwać w ten sposób skrzypce, czy sam smyczek - określenie to jakby „odstaje” od wcześniejszego

25 Józef W. Reiss, Polskie skrzypce i polscy skrzypkowie, Warszawa 1946, s. 9.

26 Por. Władysław Stróżewski, dz.cyt., s. 16.

27 Zob. Cyprian Norwid, O Juliuszu Słowackim (VI, 423-426). 
sposobu przedstawienia instrumentu. Sprawia, że można zapomnieć o jego fizycznych walorach, a przecież, jako wytwór sztuki lutniczej, skrzypce potrafią zachwycić nie tylko barwą wydawanego dźwięku, ale także swoim kształtem i kolorem. Można się domyślać, że dla Norwida - zainteresowanego także sztukami plastycznymi - miało to znaczenie. Na wygląd instrumentów muzycznych, jak pisał Stróżewski, „jego oko malarza musiało być szczególnie wrażliwe”28.

Skrzypce zbudowane z drewna „wziętego” z czarnoleskiej lipy są c z y m ś wi ię c ej niż zwykłym instrumentem. Sformułowanie „złamek drewna” wybrzmiewa zupełnie inaczej, jakby odwodząc odbiorcę od wcześniejszego skojarzenia. Jednak ów „złamek drewna” zostaje przekazany artyście niejako wraz z jego powołaniem - z zaszczytną misją, którą zadaje mu „zaklęta królewna” - misją, na której cel wskazują ostatnie słowa królewny: „I powiesz: «Prawda!...» - a ja się obudzę...” (I, 269).

W jaki sposób muzyk-instrumentalista ma w y p o w i e d z i e ć ową „Prawdę"? W jaki sposób można w ogóle m ó w i ć poprzez muzykę? Warto może zatrzymać się ponownie nad metaforą z początku utworu. Cenne są uwagi Stróżewskiego dotyczące statusu „pieśni” u Norwida:

Te dwie rzeczywistości artystyczne: pieśń - utwór poetycki, i pieśń utwór muzyczny, łączą się jednak ze sobą i wtedy, gdy nie składają się na jedno dzieło, a więc pieśń w ścisłym znaczeniu tego słowa. Dzięki temu, że jednakowa jest ich geneza, mają jak gdyby wspólny mianownik, mogą więc być sprowadzane do siebie nawzajem. To właśnie dlatego deski skrzypiec skojarzyć się mogą z lipą czarnoleską: narzędzie muzyczne $\mathrm{z}$ „narzędziem” poetyckiej inspiracji. A co jeszcze ważniejsze: wydaje się, że muzyce wolno będzie stawiać wymagania właściwe poezji, na nią zaś przenieść te, jakie się stawia muzyce ${ }^{29}$.

W Lekcji IV O Juliuszu Słowackim Norwid pisał: „Człowiek na to przychodzi na planetę, ażeby dał świadectwo prawdzie” (VI, 434).

\footnotetext{
28 Bartłomiej Łuczak, dz.cyt., s. 94. Cytowane w ostatnim zdaniu tego fragmentu słowa pochodzą z: Władysław Stróżewski, dz.cyt., s. 16.

29 Władysław Stróżewski, dz.cyt., s. 23.
} 
Określony w ten sposób cel ludzkich działań był głównym punktem odniesienia dla filozofii twórczej oryginalności. W liryku skierowanym do Biernackiego skrzypkowi zostało wyznaczone podobne zadanie. Przypomnijmy w całości „przesłanie” przekazane mu przez „Zaklętą królewnę":

I powiedziała, wstążką wiejąc czarną:

„Idź w świat, przez uczuć zwariowaną dramę,

Napatrz się w zorzę, łunę zwiedź pożarną,

Wschodnich się dowiedz tęcz, blasków zachodnich;

Co kłamać wolno, to lepiej skłam od nich,

Żywy - wybladłą porusz dijoramę!

Lecz-skoro kłamstwo zdradzisz kłamstwem sztuki,

Bądź wpierw pod lauru szerokiego cieniem,

Gdzie donieść krzywe nie potrafią łuki

Urągowiskiem albo zapomnieniem...

Aż inny ówdzie, gdzie upadną strzały,

Przyjdzie je zebrać, jak Ty zbierasz cudze,

I wspomni Ciebie, ła t w i e j- d o s k o n a ły,

I powiesz: «Prawda!...» - a ja się obudzę...”.

[I, 268-269]

Działalność artysty prowadzić ma zatem do objawienia „Prawdy”, która zbudzi kiedyś ową „zaklętą królewnę”. W podobnym duchu wybrzmiewają słowa Promethidiona, gdy autor pisze o „wieszczu”, który „z pięk nośc i wychodzi poczucia”, a który ma odsłaniać „plejadę błękitnej prawdy” (III, 456). W wierszu Do Nikodema Biernackiego Norwid również posługuje się określeniem „wieszcz” - właśnie w odniesieniu do skrzypka. Należy też zwrócić uwagę, że „zaklęta królewna” wypowiada swoje słowa, „wstążką wiejąc czarną”. Pozwala to utożsamiać jej sen ze śmiercią, jej oczekiwanie na przebudzenie zaś - z nadzieją na zmartwychwstanie ${ }^{30}$. Raz jeszcze pozwolę sobie sięgnąć po zapisaną już w moim wcześniejszym artykule uwagę:

30 Por. Bartłomiej Łuczak, dz.cyt., s. 112. 
Owa „Prawda!...” to coś więcej niż tylko stwierdzenie czy nawet podniesienie głosu w słusznej sprawie. Pod tym pojęciem, które wydaje się stanowić o istocie całego wiersza, kryje się ożywiająca moc sprawcza $^{31}$.

Powołaniem artysty nie jest - wedle myśli Norwida - kreowanie własnej artystycznej nieśmiertelności na wzór Horacjański, ale tworzenie dzieł, które poprzez piękno - „A piękność k s z t a ł t e m Prawdy i Miłości” (III, 456) - staną się inspiracją do „pracy” podejmowanej w celu odzyskania nieśmiertelności prawdziwej, mającej teologiczne znaczenie - jak pisał poeta: „by się zmartwychwstało”32. Wieszcz-skrzypek otrzymuje w tym celu „złamek drewna” (z czarnoleskiej lipy?), aby za jego pomocą wypełnić swoją artystyczną misję.

\section{Summary \\ The Linden of Czarnolas Motif in Cyprian Norwid's Works in the Context of his Thinking about Art}

The article offers an interpretation of the linden of Czarnolas motif present in Norwid's poem Do Nikodema Biernackiego from 1857 and his letter to Józef Bohdan Wagner from 1874. The author touches upon Norwid's artistic identity in the context of the poet's rooting in the Renaissance culture. Furthermore, Łuczak attempts to cast some light on the Norwidian category of originality, which was tightly related to his thinking about art. The article points to how Norwid perceived various ways in which artists processed folk culture. Finally, the article underscores the concurrence of references to aesthetic issues which the nineteenth-century poet makes in multiple texts.

Bartłomiej Łuczak (Uniwersytet Mikołaja Kopernika w Toruniu) - doktorant w Instytucie Literatury Polskiej UMK, autor kilku artykułów naukowych i publicystycznych, współredaktor książki Karol Wojtyła / Jan Paweł II wobec tradycji kultury polskiej (Torun 2015). Temat rozprawy doktorskiej: Tematy i motywy muzyczne w twórczości Cypriana Norwida.

31 Tamże.

32 Cyprian Norwid, Promethidion, III, 440. 